or to hydroxytryptamine as the assay uterus was treated with atropine and dibenamine. Hypothalamic extracts did not prevent the inactivation of added 'Pitocin' (Parke Davis) by thioglycollate. Some properties of the residual activity of hypothalamic extracts after thioglycollate are: (1) it is retained during dialysis by a 'Cellophane' membrane ; (2) its dose response curve on the virgin rat uterus is not significantly dissimilar to that of 'Pitocin' (Parke Davis) or to that of the residual activity in blood extracts ; (3) it is stable on boiling for short periods ; (4) it loses potency if stored at $5^{\circ} \mathrm{C}$. for several days (as does 'Pitocin' in dilute solution); (5) it is not recoverable in significant amounts if the hypothalamus is left in the animal for $30 \mathrm{~min}$. after death.

Thus it appears that, in addition to oxytocin, there is in hypothalamic extracts and in some blood extracts a substance which stimulates the sensitized virgin rat uterus treated with atropine and dibenamine, which is non-dialysable and the activity of which is not destroyed by treatment with thioglycollate. We are examining the properties of these substances on other means, for example, milk ejection, guinea pig ileum, to determine whether or not they are identical, and also we are endeavouring to observe whether or not a change in hypothalamic content of this second oxytocin can be correlated with changes in blood-levels of it.

Department of Pharmacology,

$$
\text { P. A. Robertson }
$$

University of Sydney.

Department of Physiology, University of Queensland, Brisbane. April 25.

${ }^{2}$ Hawker, R. W., and Robertson, P. A., J. Clin. Endocrinol. Metab. 17, 448 (1957); Endocrinol., 60, 652 (1957).

2 Bisset, G. W., and Walker, J. M., J. Physiol., 126, 588 (1954).

${ }^{3}$ Van Dyke, H. B., Chow, B. F., Greep, R. O., and Rothen, A., J. Pharmacol. Exp. Therap., 74190 (1942).

\section{Alloxan Diabetes in the Piglet}

LUKENS $^{1}$ depancreatized young pigs, and found that the diabetic state which followed was characterized by a slight or absent fasting glucose-excretion, and a low fasting nitrogen-excretion. Ketonuria was marked, but was not accompanied by severe acidosis. These observations are in contrast with those on the depancreatized cat or dog, and the question arises whether a pure beta-cell deficiency diabetes induccd by alloxan in the pig is also different from the corresponding condition in other animals. No account of this form of experimental diabetes in the pig has been found in the literature, and this is a preliminary report on the effects of alloxan on the young pig.

The piglets used in these experiments (Landrace $\times$ Large White or Large White $\times$ Large White) were installed at about two weeks of age in funnel type metabolism cages, equipped for the measurement of food and water intakes and the 24-hourly collection of urine under toluene. The pellet diet used throughout was 'Amvilac No. 2' (Glaxo). Blood samples for glucose estimation' ${ }^{2}$ were taken from the tail, and urine glucose was estimated by Benedict's quantitative method. Room temperature was maintained at approximately $70^{\circ} \mathrm{F}$. Alloxan was injected as a freshly prepared 7-10 per cent solution in 0.9 per cent sodium chloride solution, in animals weigh-
Table 1

\begin{tabular}{|l|c|c|}
\hline & Control & $\begin{array}{c}\text { Diabetic } \\
\text { (maximum } \\
\text { values) }\end{array}$ \\
\hline Total food eaten in 8 consecutive days & & \\
(kgm.) & $3 \cdot 55$ & $3 \cdot 75$ \\
Weight gain over same 8 days (kgm.) & $2 \cdot 90$ & $1 \cdot 50$ \\
Urine (mal./24 hr.) & 550 & 7,000 \\
Glycosuria (gm./24 hr.) & 0 & 376 \\
Blood-sugar, feeding (mgm./100 ml.) & $80-117$ & 605 \\
Blood-sugar, fasting (mgm./100 ml.) & $38-83$ & 303 \\
\hline
\end{tabular}

ing $5 \mathrm{kgm}$. or more; the controls received 0.9 per cent sodiurn chloride solution. All injections were made by the intracardiac route to ensure rapid entry of alloxan into the blood.

Fourteen piglets were injected with alloxan in doses ranging from 75 to $250 \mathrm{mgm} . / \mathrm{kgm}$. body weight; of these, six piglets were made glycosuric, including three marked diabetics. No measurable urinary ketosis (that is, more than 1 part per 100,000) was observed at any time. The effective dose of alloxan was $200-250 \mathrm{mgm} . / \mathrm{kgm}$. body-weight by intracardiac injection after a fast of $20-24 \mathrm{hr}$.; if the animal was not fasted it showed marked resistance to the diabetogenic effect of alloxan (cf. ref. 3). The blood-sugar and urinary glucose excretion rose together; the maximum values observed are compared with control values in Table 1 (pigs weighing approximately $8 \mathrm{kgm}$.).

The alloxan diabetic pig showed a diabetic type of response to the intravenous glucose test $(0.5 \mathrm{gm}$. glucose/kgm.), and the glycosuria and urinary nitrogen were approximately parallel to the food intake. Weight gain continued, although at a reduced rate; the animal was relatively insensitive to insulin.

Differential staining of pig pancreas is difficult; the best procedure found so far includes Zenkerformol fixation and staining by Gomori's chromehæmatoxylin phloxine ${ }^{4}$, which allows differentiation of alpha and beta cells and acinar tissue. Pancreas from a pig treated effectively with alloxan shows an absence of beta cells while the alpha cells remain readily apparent.

Alloxan diabetes in the young piglet appears to be similar to alloxan diabetes in some other species. The dose, at 200-250 mgm./kgm., is high as compared with the dog (60-75 mgm. / $\mathrm{kgm}$.) or mouse (100 mgm.) kgm.), but not in comparison with the monkey $(300 \mathrm{mgm} . / \mathrm{kgm} .)^{5}$. The diabetic piglets were followed for three weeks; during that time they did not appear ill, blood-sugar was high, there was no apparent ketosis and they were relatively insensitive to insulin. Despite the unusual features of the depancreatized pig noted earlier, the relation the alloxan diabetic pig bears to the depancreatized pig of comparable weight appears similar to the relation between alloxan diabetic and depancreatized $\operatorname{dog} 8^{6}$, in that the alloxan diabetic showed higher blood-sugars, no severe ketosis, and no dependence on insulin.

I wish to thank A. Legge for technical assistance.

Agricultural Research Council

Institute of Animal Physiology, Babraham, Cambridge. May 2.

${ }^{1}$ Lukens, F. D. W., Amer. J. Physiol., 118, 321 (1937).

'Somogyi, M., J. Biol. Chem., 195, 19 (1952).

Kass, E. H., and Waisbren, B. A., Proc. Soc. Exp. Biol., 60, 303 (1945).

- Gomori, G., Amer. J. Path., 17, 395 (1941).

'Lukens, F. D. W., Physiol. Rev., 28, 304 (1948).

Thorogood, E., and Zimmermann, B., End., 37, 191 (1945). 